\title{
Mancha negra do abacaxi no Pará
}

\author{
Jaqueline Rosemeire Verzignassi ${ }^{1}$, Aristóteles Pires de Matos $^{2}$, Maria de Fátima Santos ${ }^{3}$, Luiz Sebastião Poltronieri ${ }^{4}$, \\ Ruth Linda Benchimol ${ }^{4}$, Nilton Fritzons Sanches ${ }^{2}$
}

${ }^{1}$ Embrapa Gado de Corte, Rod. BR 262, Km 4, Caixa Postal 154, CEP 79002-970, Campo Grande, MS, e-mail: jaqueline@cnpgc.embrapa.br. ${ }^{2}$ Embrapa Mandioca e Fruticultura Tropical, Cruz das Almas, BA. ${ }^{3}$ Amazônia Oriental, Tv. Enéas Pinheiro, S/N, CEP 66095-100, Belém, PA. ${ }^{4}$ Agência de Defesa Agropecuária do Pará, Belém, PA.

Autor para correspondência: Jaqueline Rosemeire Verzignassi

Data de chegada: 10/07/2007. Aceito para publicação em: 03/09/2008

1512

O abacaxizeiro (Ananas comosus (L.) Merrill) é uma espécie tropical de grande interesse econômico para o Pará. Em 2004, o Estado produziu 315.428 mil frutos de abacaxi, seguido pela Paraíba (268.106 mil frutos), Minas Gerais (219.137 mil frutos) e Bahia (117.973 mil frutos). Em 2005, tornou-se o segundo maior produtor, com 268.808 mil frutos, superado pela Paraíba, com 325.612 mil frutos. Em 2006, tornou-se o maior produtor brasileiro, com área colhida de 14.062 ha, produção de 353.773 mil frutos e rendimento médio de 25.158 frutos por hectare. Floresta do Araguaia é o maior produtor de abacaxi do Pará, com cerca de 12,5 mil ha de área plantada, 18 milhões de frutos por safra e rendimento médio de $27 \mathrm{t} / \mathrm{ha}$, correspondendo a aproximadamente $15 \%$ da produção nacional. O Município apresenta a maior indústria de suco concentrado da fruta do Brasil, exportando para os países da União Européia, Estados Unidos, Israel e Mercosul, e é seguido por Salvaterra, Conceição do Araguaia e, no Nordeste Paraense, por Capitão Poço e Castanhal e, nestes últimos, tem ocorrido grande expansão da cultura nos últimos anos. Em Floresta do Araguaia, a abacaxicultura em escala comercial, foi iniciada na segunda metade da década de oitenta. Embora existam pequenos produtores, as áreas cultivadas com abacaxizais são relativamente médias a grandes, havendo produtores com mais de 1.200 .000 pés.

Frutos da cv. Pérola, com ausência de lesões externas, com coloração amarelada e apresentando lesões internas de coloração marrom clara a escura, foram coletados em plantios comerciais de Floresta do Araguaia, Mojú, Salvaterra e Bragança. A partir das lesões, procedeu-se o isolamento em meio BDA. Colônias fúngicas, brancas a róseas, e colônias esverdeadas, com micélio aéreo e amareladas no reverso da placa, surgiram após três dias do isolamento. Foram identificados Fusarium moniliforme Sheldon e Penicillium funiculosum Thom, agentes causais da mancha negra do fruto. Frutos sadios da mesma cultivar, previamente desinfestados, foram inoculados com ambos os isolados. Para tanto, os frutos foram perfurados com vasador de rolha ( $1 \mathrm{~cm}$ de diâmetro) e discos de micélio + meio de cultura de ambos os isolados foram inseridos nos orifícios, os quais foram vedados com a parte retirada pelo vasador. Na testemunha, inseriu-se apenas discos de meio de cultura. Os frutos foram submetidos à câmara úmida por dois dias e, quatro dias após a inoculação, verificou-se sintomas similares aos observados nos frutos das áreas de cultivo. Efetuou-se o reisolamento a partir das lesões formadas e obteve-se os dois fungos inoculados. Este é o primeiro relato de mancha negra do abacaxi no Pará.

A mancha negra do fruto é atribuída a um complexo de agentes, incluindo fungos e ácaros. A doença é favorecida pelos ferimentos provocados pelo ácaro do abacaxi (Steneotarsonemus ananas Tryon) e o ácaro alaranjado (Dolychotetranychus floridanus Banks), que

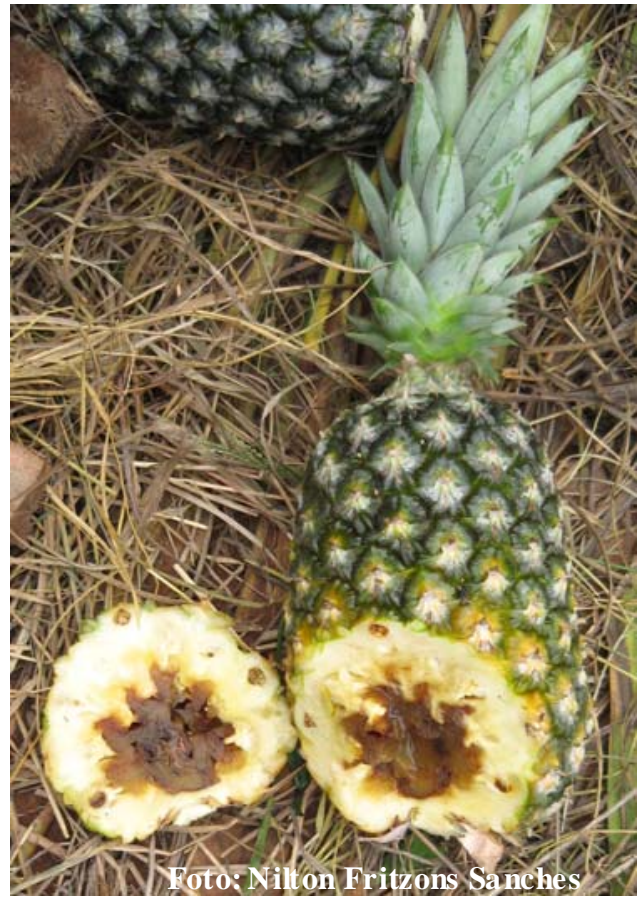

Figura 1. Abacaxi com sintomas internos da mancha negra.

causam necroses nas brácteas e sépalas das flores em desenvolvimento e na base das folhas próximas às inflorescências, favorecendo as infecções pelos fungos F. moniliforme e/ou P. funiculosum. A ocorrência de períodos chuvosos, seguidos de períodos secos, antes da abertura das flores, resulta em alta incidência da doença nos frutos os quais perdem o valor comercial devido ao apodrecimento da polpa, resultando em prejuízos acentuados ao produtor. O controle da mancha negra do fruto é uma prática bastante difícil, baseando-se no controle químico dos ácaros durante o período de maior suscetibilidade da inflorescência. Em outras regiões produtoras do mundo, a mancha negra do abacaxi é controlada mediante pulverizações com endosulfan, para o controle dos ácaros, iniciadas logo após a indução floral e encerradas quando do fechamento das flores. No Brasil, o produto não é registrado pelo Ministério da Agricultura, Pecuária e Abastecimento para uso em abacaxizeiro. A sobrevivência de F. moniliforme nos restos da cultura não é relatada na literatura. Adiciona-se que o patógeno não produz clamidósporos (estruturas de resistência). Além do controle químico, a ocorrência de isolados avirulentos de $P$. funiculosum, capazes de reduzir a incidência da mancha-negra do fruto do abacaxizeiro em condições de campo, no Havaí, sugere a possibilidade do controle biológico dessa doença. 